Review

\title{
Wine and Grape Tannin Interactions with Salivary Proteins and Their Impact on Astringency: A Review of Current Research
}

\author{
Jacqui M. McRae ${ }^{1, *}$ and James A. Kennedy ${ }^{2}$
}

1 The Australian Wine Research Institute, PO Box 197, Glen Osmond SA 5064, Australia

2 Department of Viticulture and Enology, California State University, 2360 E. Barstow Ave MS VR89, Fresno, CA 93740, USA; E-Mail: jakennedy@csufresno.edu

* Author to whom correspondence should be addressed; E-Mail: Jacqui.McRae@awri.com.au; Tel.: +61 8 83136600; Fax: +61 883136601 .

Received: 9 February 2011; in revised form: 2 March 2011 / Accepted: 9 March 2011 /

Published: 11 March 2011

\begin{abstract}
Astringency is an important characteristic of red wine quality. The sensation is generally thought to be produced by the interaction of wine tannins with salivary proteins and the subsequent aggregation and precipitation of protein-tannin complexes. The importance of wine astringency for marketability has led to a wealth of research on the causes of astringency and how tannins impact the quality of the sensation, particularly with respect to tannin structure. Ultimately, the understanding of how tannin structure impacts astringency will allow the controlled manipulation of tannins via such methods as microoxygenation or fining to improve the quality of wines.
\end{abstract}

Keywords: astringency; condensed tannin; salivary proteins; wine

\section{Introduction}

Tannins, including grape-derived condensed tannins (flavonoids) produce sensations of astringency in food and drink and form the 'structure' or 'body' of red wine. The term astringency refers to the drying and a puckering sensation in the mouth [1] and is a characteristic of red wine and its mouth-feel [2-5]. Wine tannin quality is dependent on the maximum intensity of the mouth feel, total duration and time taken to reach maximum intensity [6], as well as the extent of mouth drying and mouth roughness $[1,7,8]$. The spectrum of subtle differences in astringency sensations was compiled as a 'red wine 
mouth-feel wheel' by Gawel et al. [9], which include such descriptors as 'powder' through to 'adhesive' and 'aggressive'. Astringent sensations of wine are considered pleasant when balanced with other factors including alcohol and sugar content. Higher concentrations of tannins and acids compared with sugar results in a highly astringent wine that is considered 'harsh', 'unripe' or 'green', and conversely, higher concentrations of sugars can result in a wine that may be described as 'thick' or 'flabby' [10]. Astringency influences the quality of red wine [11,12] and therefore knowledge of the structures of astringent compounds in a wine matrix and the impact of these structures on the sensory properties can be an important aspect of winemaking.

Tannins characteristically have a propensity to bind to proteins and therefore can potentially cause gastrointestinal problems by denaturing digestive enzymes in the gut. Salivary proteins are believed to bind efficiently to tannins to offset this effect and also to act as a detection mechanism [13-15]. The resulting aggregation of the protein-tannin complexes and subsequent increase in friction is generally thought to give rise to the sensation of astringency [14,16], however these interactions are only part of the complex sensation that can give a range of perceptions from a velvety smooth texture to a harsh, puckering sensation $[9,17,18]$.

The astringency of wine is influenced by a number of factors, including the structures and quantity of the tannin in wine [19], the presence of macromolecules such as polysaccharides [20,21] and residual sugars [22], the concentration of smaller molecules such as anthocyanins and catechin monomers [7,23], the acidity [24,25], and ethanol concentration [8,24]. Ultimately the understanding of how different wine constituents contribute to astringency will enable growers and winemakers to have more control over the characteristics of the produced wine.

\section{Mechanisms of Astringency}

Astringency is a complex process involving many mechanisms and is generally considered to be a tactile sensation caused by a loss of lubricity in oral saliva $[6,26]$. The exact mechanisms of this process are not well understood, yet many factors are known to contribute to an astringent sensation, including an increase in friction [26,27], interactions between tannins and oral epithelial proteins [28] or with taste receptors, particularly bitter receptors in the case of small condensed tannins [6,7,29], and a change in saliva viscosity [30]. These factors are summarized here and are covered in more detail in the review by Bajec and Pickering [31].

The main mechanism behind the loss of saliva lubricity is thought to result from the interaction of astringent agents, such as tannins, with salivary proteins and glycosaminoglycans (mucopolysaccharides). The subsequent aggregation and precipitation of the protein-tannin complexes has been shown to reduce the lubricity of saliva by increasing friction in the oral cavity $[14,16,32]$. This process causes a drying and grainy sensation in the mouth and the sensation has been shown to differ based on the size and concentration, as well as the hardness or softness, of the precipitate $[27,33]$. The formation of soluble aggregates between hydrolysable tannins and gelatin in vitro has also shown to produce an astringent sensation in vivo, suggesting that precipitation is not a necessary to induce an astringent sensation [34]. Any remaining unbound tannins may interact with other oral surfaces, and experiments by Payne et al. [28] have demonstrated that tannins also interact with oral epithelial cells. This interaction was increased at lower $\mathrm{pH}$, which correlated directly with an increase 
in perceived astringency. Further, tannins and their analogues may degrade in solution [35] and thus interact with taste receptors, particularly the bitter receptors $[29,36]$.

The physiological response of the individual tasting the wine will also influence how they perceive the wine astringency. Salivary flow rate, viscosity and protein composition vary between people and the latter has been shown to have a significant effect on perceived astringency [8,14,37]. Higher concentrations of particular saliva proteins and a higher flow rate of saliva have been shown to generally reduce the sensation of astringency [6,37]. Saliva viscosity is not directly correlated with oral lubrication, however the sensation of astringency can be produced by a decrease in saliva viscosity, which thus increases friction [27].

Astringency involves many factors, however the key element in the development of this sensation is that astringent agents, particularly tannins, interact with proteins in saliva. The exact composition of saliva varies among individuals, it is generally reported as comprising mostly of proline-rich proteins (PRPs) as well as histidine-rich proteins (histatins or HRPs), $\alpha$-amylase, lactoferrin, and mucinglycoproteins [13,31,37,38], with PRPs and HRPs being the main tannin-binding proteins. Details of other tannin-binding salivary components are described in a review by Bennick [39]. PRPs are intrinsically unfolded proteins consisting of multiple tandem repeats, which provide numerous binding sites for interactions with tannins [40-43], particularly those amino acids that form part of a polyproline (PPII) helix [44].

PRPs are sub-classified as either basic, acidic or glycosylated proteins based on differences in amino acid sequences [21,31]. Basic PRPs amount to around 23\% of PRPs in human parotid saliva and are involved directly with binding to food tannin to prevent it from inhibiting digestion enzymes in the stomach $[39,43]$. The amino acid sequences of many of these proteins have been determined and IB5 in particular has been widely used as a model PRP for many tannin-protein interaction studies due to its low complexity and representative structure [43-45]. Basic PRPs have been proposed as being the main tannin-binding PRPs [46], which may be due to the extended conformations of these proteins [47]. Acidic and glycosylated PRPs have also been found to bind to hydrolysable tannins [48], as well as flavanol polymers and monomers [49], suggesting that they may also contribute to the sensation of astringency. Acidic PRPs make up around 30\% of known PRPs and are known to have a high affinity for binding with calcium and may therefore be part of the dental pellicle $[39,46,48]$. Glycosylated PRPs are the least abundant, incorporating only 17\% of known PRPs and are responsible for oral lubrication and antibacterial activity [44]. Complexes of tannin and glycosylated PRPs have been shown to remain soluble, whereas complexes with non-glycosylated PRPs are more likely to precipitate from solution [50] although the impact of these findings on astringency is not known.

Histidine-rich proteins also important tannin-binding proteins in saliva, but only constitute $2.6 \%$ of salivary protein. They tend to be smaller than PRPs with histidine making up about a quarter of the amino acids present. Twelve different HRPs (HRP1-12) have been isolated from human saliva and their structures determined, with HRPs 1, 3 and 5 accounting for the vast majority of these proteins. All three HRPs have been found to bind and precipitate hydrolysable tannins, although HRP 1 demonstrated reduced capacity for precipitating condensed tannins compared with HRP 3 and 5 $[51,52]$. The extended structure and natively unfolded nature of PRPs and HRPs also allow access to binding sites more readily than proteins with more globular configurations including amylase $[38,45]$. 
The structures of salivary proteins, as well as those of the wine tannins, impact upon the extent of protein-tannin interactions in the oral cavity and thus influence the resulting astringency of wine.

\section{Red Wine Tannins}

Red wine tannins consist of condensed tannins extracted from grapes and subsequently structurally modified during wine-making. A small percentage of hydrolysable tannins are extracted from oak barrels or chips during aging [53], however these compounds alone are unlikely to contribute to astringency [54]. Condensed tannins from grape skins are extracted earlier in the fermentation process. As fermentation continues, tannins begin to be extracted from grape seeds and flesh $[55,56]$. Cold soaking of grapes has also been shown to increase the extraction of seed tannins in the absence of ethanol, which may be related to the softening of the seeds prior to fermentation [57].

Grape skin tannins consist of long polymeric chains ranging from 3 to 83 flavanol subunits (degrees of polymerization, DP) and are composed of procyanidins and prodelphinidins [29,58-62]. The trihydroxylated prodelphinidin subunits consist mainly of epigallocatechin (1, Figure 1), but with trace amounts of gallocatechin (2, Figure 1) and epigallocatechin 3-O-gallate (3, Figure 1) [62]. The tannin extracted from the skin of commercially ripe grapes consists of a portion of anthocyanins covalently bound to the oligomeric condensed tannins [63]. In the major winegrape varieties, anthocyanins include malvidin- (4), cyanidin- (5), peonidin- (6), petunidin- (7) and delphinidin- (8) 3-O-glucosides (Figure 2) [2,64], which may be incorporated into the structure of skin tannins. Seed tannins have a lower average degree of polymerization than skin tannins and are composed mainly of catechin (9, Figure 1) and epicatechin (10, Figure 1) subunits, with a greater proportion of galloylated units (13$29 \%$ ) compared with skin tannins (3-6\%) [65,66]. The size of seed tannins has been reported as between DP 2 to 17 [29,66-68]. The smaller molecular weight of seed tannins may be the reason for the reported bitterness of these compounds, and this may explain why seed tannins are considered undesirable in wine $[65,69]$. Flesh tannins exhibit greater molecular mass than seed tannins and comprise both epicatechin gallate and epigallocatechin subunits [68]. Grape stem tannins can contribute to the phenolic composition of wine and potentially increase the tannin concentration. The Dp of stem tannins ranges from 4 to 28 , with a lower proportion of epigallocatechin subunits compared with epicatechin gallate subunits [70,71].

During fermentation, the structure of the extracted grape tannin is altered by enzymatic and chemical oxidation processes as well as indirect condensation reactions [64,65,72], which are facilitated by oxidation products such as acetaldehyde pyruvic acid and glycoxylic acid [73-75]. For example, acetaldehyde-mediated condensation reactions initially may involve the formation of ethyllinked procyaninidin oligomers or pigmented polymers [76,77]. These can further polymerize to form coloured tannins that are potentially more prone to folding and intramolecular bonding than the more linear structures of grape tannins [78]. Wine tannin structure is less understood than grape tannin structure, which is largely because the structure is more resistant to traditional methods of tannin analysis such as acid-catalysed cleavage of the interflavan bonds and subsequent thiolysis or reaction with phloroglucinol $[78,79]$.

After fermentation, wine constituents continue to undergo chemical changes which influence the structure of the tannin content. The acidic and slow oxidative conditions in wine lead to bond breaking and rearrangement reactions $[33,80]$, which are thought to cause the polymerization of tannins, as well 
as the formation of different pigments and pigmented polymers [81-84]. Tannins from aged wines also have a greater quantity of coloured anthocyanins incorporated into the structure than tannins isolated from young wines [79] and this, to at least some extent, accounts for the decrease in anthocyanin concentration in wine with aging $[85,86]$. Oxidized tannins have been shown to feature greater intramolecular interactions, altering the conformation of the tannin in solution to more condensed or folded structures rather than the extended forms of grape tannins [78]. The changes in tannin structure with grape fermentation and wine aging are likely to impact upon the binding of the tannin with salivary proteins and thus the astringency of the wine.

Figure 1. Structures of condensed tannin subunits (flavan-3-ol monomers)<smiles>[R9]c1cc([C@@H]2Oc3cc(O)cc(O)c3CC2([2H])[2H])cc(O)c1O</smiles><smiles>O=C(O[Al])c1cc(O)c(O)c(O)c1</smiles>

\begin{tabular}{ccccc}
\hline & Flavan-3-ol Monomer & $\mathbf{R}_{\mathbf{1}}$ & $\mathbf{R}_{\mathbf{2}}$ & $\mathbf{R}_{\mathbf{3}}$ \\
\hline $\mathbf{1}$ & Epigallocatechin & $\mathrm{OH}$ & $\mathrm{H}$ & $\mathrm{OH}$ \\
$\mathbf{2}$ & Gallocatechin & $\mathrm{H}$ & $\mathrm{OH}$ & $\mathrm{OH}$ \\
$\mathbf{3}$ & Epigallocatechin 3-O-gallate & $\mathrm{O}-\mathrm{Gal}$ & $\mathrm{H}$ & $\mathrm{OH}$ \\
$\mathbf{9}$ & Catechin & $\mathrm{H}$ & $\mathrm{OH}$ & $\mathrm{H}$ \\
$\mathbf{1 0}$ & Epicatechin & $\mathrm{OH}$ & $\mathrm{H}$ & $\mathrm{H}$ \\
\hline
\end{tabular}

Figure 2. Structures of anthocyanins in wine.<smiles></smiles>

\begin{tabular}{lccc}
\hline & Anthocyanidin & $\mathbf{R}_{\mathbf{1}}$ & $\mathbf{R}_{\mathbf{2}}$ \\
\hline $\mathbf{4}$ & Malvidin & $\mathrm{OCH}_{3}$ & $\mathrm{OCH}_{3}$ \\
$\mathbf{5}$ & Cyanidin & $\mathrm{H}$ & $\mathrm{OH}$ \\
$\mathbf{6}$ & Peonidin & $\mathrm{OCH}_{3}$ & $\mathrm{H}$ \\
$\mathbf{7}$ & Petunidin & $\mathrm{OCH}_{3}$ & $\mathrm{OH}$ \\
$\mathbf{8}$ & Delphinidin & $\mathrm{OH}$ & $\mathrm{OH}$ \\
\hline
\end{tabular}

\section{Protein-Tannin Interactions and Astringency}

From model studies it has been shown that tannins bind to proteins in three distinct stages. Initial interactions involve both hydrophobic interactions and hydrogen bonding and result in the formation of protein-tannin complexes. Hydrophobic interactions are entropy-driven and include Van der Waals interactions or $\pi-\pi$ stacking of the electron-rich phenol ring of the tannin B-ring or galloyl ester and the 
planar pro-S face of the heterocyclic amide bonds in proline [16,41]. Hydrogen bonding is an enthalpy-driven electrostatic interaction that occurs between the tertiary amide or carbonyl groups of a proline subunit of a PRP $[15,87]$ or the histidine imidazole ring or terminal carbon of an HRP, and the tannin hydroxyl groups $[52,88]$. The hydroxyl groups on the aromatic rings of condensed tannins have an acidic proton that acts as a proton donor, and a lone electron pair on the plane of the aromatic ring that functions as a proton acceptor. The ability of the tannin to bind to multiple sites on the randomlycoiled protein condenses the protein-tannin complex and making it more spherical [40].

The second stage of interaction involves the formation of protein aggregates with bound tannins, through self-association, causing cross-links between protein-tannin complexes [24,40,43]. The third stage of interaction occurs when the protein aggregates eventually coalesce producing colloidal particles that lead to precipitation of protein-tannin complexes, [14,40]. These processes have been shown to involve hydrogen bonding $[72,87,89]$. The concentration of salivary proteins affects the initial protein-tannin interaction, while environmental factors including $\mathrm{pH}$, ionic strength and temperature influence the precipitation of formed aggregates in the second and third stages of interaction [90]. Differences in the size and hardness of the precipitate can impact upon the perceived astringency [22].

Greater concentrations of tannins have been shown to correlate directly with increases in perceived astringency $[3,19]$, and differences in tannin structures have been shown to have a substantial impact upon the efficacy of protein binding as well as the perception of astringency [22,91,92]. Enhanced protein binding has been reported from tannins of greater molecular size and structural flexibility, containing a greater proportion of catechin subunits to epicatechin or epigallocatechin subunits, and more C4-C8 bonds than C4-C6 bonds [20,41,93,94]. Larger tannins with greater structural flexibility, such as freely rotating interflavan bonds and gallate groups, have a greater propensity to bind to proteins due to a larger number of available binding sites for interaction with the proline or histidine residues $[16,65,95,96]$. The increased size of the tannin also permits greater self-association, thereby promoting complex aggregation. The correlation between tannin size and efficacy in protein binding has been shown to have an upper limit depending on the tannin structure, since steric hindrance can prevent access to binding sites and greater molecular weight may limit solubility $[16,97]$. The presence of anthocyanins in the tannin structure also reduces the protein-binding capacity of the compound [65], although pigmented polymers have also been found to be positively associated with a puckering sensation $[11,22]$.

The conformation of tannins in solution has been shown to substantially affect the protein-binding efficacy of tannins. Flavan-3-ol subunits linked through a C4-C8 bond, such as procyanidin B3 (11, Figure 3). This results in a comparatively extended and more linear structure than C6-C8 bonds, such as procyanin B5 (12, Figure 3), which potentially enables greater interaction with more binding sites proteins rather than greater intra-molecular bonding [38]. Further, the stereochemistry of the 4-8 interflavan bond is dependent on the flavan-3-ol isomer of the upper subunit, relating to either a catechin derivative or epicatechin derivative, respectively. Catechin subunits reportedly have a higher specificity for PRPs relative to the epi-isomer, and these results also correlate with an increase in the perception of astringency for catechin compared with epicatechin [7,38,98], further demonstrating the stereo-specific binding nature of condensed tannins. The subsequent stereochemistry of the interflavan bond between these subunits may also influence the conformation of the formed polymer, resulting in 
the dominance of either an extended or compact form $[99,100]$. Both configurations have been shown to have a strong affinity for PRPs, with extended polymers promoting the formation of aggregates and compact polymers demonstrating greater hydrophilic interactions [72,87].

Figure 3. Structures of procyanidin dimers B3 (11) and B5 (12).<smiles>Oc1cc(O)c2c(c1)O[C@H](c1ccc(O)c(O)c1)[C@H](O)[C@H]2c1c(O)cc(O)c2c1O[C@H](c1ccc(O)c(O)c1)[C@H](O)C2</smiles><smiles>C[C@@H]1Cc2c(cc(O)c([C@H]3c4c(O)cc(O)cc4O[C@H](c4ccc(O)c(O)c4)[C@@H]3O)c2O)O[C@H]1c1ccc(O)c(O)c1</smiles>

The aging of wine gradually alters the purple hue of young wine to brick-red and is considered to render the tannins less astringent. The change in hue is related to the formation of more stable pigments such as vitisin A and B and their derivatives from grape anthocyanins [101,102], as well as oxidative browning [103]. The cause for the decrease in astringency of red wine over time remains uncertain. A decrease in tannin concentration as a result of fining by residual proteins or polysaccharides [104], polymerization and subsequent precipitation, or conversely, depolymerization of tannins may contribute to the reduction in astringency [35]. However, some aged wines reportedly have similar concentration of tannin as young wines [3] and yet aged wines are generally considered to be less astringent, which suggests that tannin structural changes may also impact upon the perceived astringency [105]. Aged wine tannins have been shown to be larger than young wine tannins [79], a characteristic that is generally correlated with greater astringency [91]. Therefore it is possible that increased intramolecular bonding due to oxidation results in reduced structural flexibility and thus protein interaction, which may impact the astringency of aged wines. Artificially oxidized tannins have also been shown to have greater hydrophobicity than 'native' tannins [33], which may also impact upon the binding efficacy.

Micro-oxygenation (MOX) involves the controlled addition of small amounts of oxygen to a wine system either during fermentation or in the initial months post fermentation [106]. The effect of the 
increased oxygen exposure on red wine may contribute to a stabilization of wine colour and improved flavor and aroma [107-109]. One of the impacts of MOX treatment may be to produce changes in tannin structure that mimic the changes produced during aging, thus changing the perceived astringency of the wine [108,110]. The long term impacts of MOX on red wine are still being investigated.

\section{The Impact of the Wine Matrix on Astringency}

The interaction of wine tannin with salivary proteins, and the size and stability of the resulting protein-tannin complexes, are also dependent on other parameters of the wine matrix, particularly the $\mathrm{pH}$ and ethanol concentrations. Additional factors, including the concentration of organic acids, sugar, available acetaldehyde concentration, viscosity, and the presence of other compounds that interact with tannins such as residual yeast proteins and grape polysaccharides, can also impact upon the perception of astringency. The serving temperature of wine was found to have a minimal impact on the sensation of astringency [111].

Ethanol concentration varies in red wine from approximately $11 \%$ to $15 \%$ and higher concentrations have been shown to decrease the perception of astringency in model wines $[24,58]$ and alter the astringency sub-qualities of wine [8], although one report indicated an increase in astringency with ethanol concentration [112]. A decrease in astringency with increasing ethanol concentration may at least in part be due to the conformational changes of tannins in higher ethanol wines. This may reduce the binding of tannins to proteins as well as the self-association of bound tannins, limiting the formation of protein aggregates [24]. Higher ethanol concentrations in model wine has also been shown to decrease the formation of protein-tannin aggregates [49,113]. Increasing ethanol concentration between 10 and $20 \%$ has also been shown to disrupt hydrophobic interactions between tannins and apple cell wall material, particularly for high molecular weight compounds with a higher degree of galloylation [98]. Further, greater ethanol concentrations may also increase the lubricity of the oral cavity, reducing the perception of roughness [8,24]. An increase in protein precipitation with ethanol concentration of $13 \%$ compared with aqueous solutions may relate to the change in solubility of the formed protein-tannin complexes [112]. Zanchi and colleagues demonstrated differences in ethanol solubility in a mixture of grape-seed tannins due to both self-aggregation [114,115] and PRPtannin aggregation [33], which is likely to relate to differences in the structure of the tannins. Changes in solubility of tannins in wine may also influence the resulting astringency [115]. Finally, an increase in viscosity of the solution with greater ethanol content may also decrease the perception of astringency as well as protein-tannin interactions $[8,30,89]$.

The $\mathrm{pH}$ of wine generally ranges from $\mathrm{pH} 3.2$ to 3.8 and this difference is sufficient to elicit changes in astringency. Lowering the $\mathrm{pH}$ of wine and model wine solutions has been shown to increase the intensity of astringency as well as increase the association of tannins with proteins $[24,116]$. This effect is more significant than increasing the concentration of individual organic acids such as malic, lactic and tartaric acid [24,25], however greater organic acid concentrations combined with greater acidity have been shown to contribute to the chalky characteristics of red wine [22]. A combination of low $\mathrm{pH}$ and high organic acid concentration was also shown to be responsible for increasing the astringency of fermented coconut sap [117]. 
Tannins have been shown to bind to residual proteins or polysaccharides in the wine matrix, thereby reducing the concentration available for salivary protein interaction and thus reducing astringency [118]. This has been demonstrated in fruit, with the decrease in astringency of ripening fruit attributed to an increase in polysaccharides rather than a decrease in tannin concentration [32,119]. Different polysaccharides reduce the astringency of tannins by different mechanisms of action. Arabic gum and $\beta$-cyclodextrin preferentially bind to polyphenols, inhibiting protein-tannin interactions, while the polyelectrolytic properties of pectin enable it to bind directly to protein/polyphenol complexes, thereby increasing the water solubility of these complexes and preventing them from precipitating out of solution [21,120-122]. The polysaccharides in wine are classified based on their net charge, either neutral or acidic. Neutral polysaccharides in wine include arabinogalactan and pectin polysaccharides from grape cell walls and mannoprotein from the yeast during fermentation, and the main acidic polysaccharide is rhamnogalacturonan II. All polysaccharides have been shown to reduce the perception of astringency by some degree, however the acidic polysaccharides have shown a greater impact on astringency reduction [20,21,66,119]. The concentration of ethanol and ionic strength of the solution have also been shown to impact tannin-polysaccharide interactions as well as tannin-protein interactions [122].

Higher concentrations of sucrose and anthocyanins in wine have been associated with lower astringency ratings in wines and reducing the unpleasant 'puckering' sensation of young wines [22,123-125]. The use of the sweetening agent, aspartame, however, had no impact on the perceived astringency of model wine, suggesting that the reported association between high sucrose concentrations and reduced astringency may have been due to the increased viscosity of the solution [30]. The presence of oxidizing agents that promote polymerization such as acetaldehyde and glycoxylic acid have been shown to increase the perception of astringency, presumably due to the increase in tannin size [23]. Ethyl-linked flavan-3-ol dimers formed from reactions with acetaldehyde have been shown to have the same astringency as non ethyl-linked flavan-3-ol dimers [23]. The interactions of these factors in the wine matrix as well as differences in tannin structures and concentrations, all impact upon the perceived astringency of red wine.

\section{Conclusions}

There has been considerable research into the mechanisms involved in wine astringency perception, the factors affecting astringency in wine and the structures of some of the contributing tannins and yet there is still a great deal to understand with respect to how the tannins present in grapes relate to wine tannins and astringency in the corresponding wine. Greater knowledge of the structure/ function relationships in protein binding, and knowledge of how tannin structure can be selectively changed to improve astringency would have important implications in winemaking.

\section{Acknowledgements}

The Australian Wine Research Institute, a member of the Wine Innovation Cluster in Adelaide, is supported by Australian grapegrowers and winemakers through their investment body, the Grape and Wine Research and Development Corporation, with matching funds from the Australian Government. 


\section{References}

1. Lee, C.B.; Lawless, H.T. Time-course of astringent sensations. Chem. Senses 1991, 16, 225-238.

2. Kennedy, J.A.; Saucier, C.; Glories, Y. Grape and wine phenolics: History and perspective. Am. J. Enol. Viticult. 2006, 57, 239-248.

3. Mercurio, M.D.; Smith, P.A. Tannin quantification in red grapes and wine: Comparison of polysaccharide- and protein-based tannin precipitation techniques and their ability to model wine astringency. J. Agric. Food Chem. 2008, 56, 5528-5537.

4. Mercurio, M.D.; Dambergs, R.G.; Cozzolino, D.; Herderich, M.J.; Smith, P.A. Relationship between red wine grades and phenolics. 1. Tannin and total phenolics concentrations. J. Agric. Food Chem. 2010, 58, 12313-12319.

5. Gawel, R.; Iland, P.G.; Francis, I.L. Characterizing the astringency of red wine: A case study. Food Qual. Prefer. 2001, 12, 83-94.

6. Kallithraka, S.; Bakker, J.; Clifford, M.N.; Vallis, L. Correlations between saliva protein composition and some T-I parameters of astringency. Food Qual. Prefer. 2001, 12, 145-152.

7. Kallithraka, S.; Bakker, J.; Clifford, M.N. Evaluation of bitterness and astringency of (+)-catechin and (-)-epicatechin in red wine and in model solution. J. Sens. Stud. 1997, 12, 25-37.

8. Demiglio, P.; Pickering, G.J. The influence of ethanol and $\mathrm{pH}$ on the taste and mouthfeel sensations elicited by red wine. J. Food Agric. Environ. 2008, 6, 143-150.

9. Gawel, R.; Oberholster, A.; Francis, I.L. A 'mouth-feel wheel': terminology for communicating the mouth-feel characteristics of red wine. Aust. J. Grape Wine Res. 2000, 6, 203-207.

10. Kennedy, J.A. Grape and wine phenolics: Observations and recent findings. Cienc. Invest. Agrar. 2008, 35, 107-120.

11. Boselli, E.; Boulton, R.B.; Thorngate, J.H.; Frega, N.G. Chemical and sensory characterization of doc red wines from Marche (Italy) related to vintage and grape cultivars. J. Agric. Food Chem. 2004, 52, 3843-3854.

12. Landon, J.L.; Weller, K.; Harbertson, J.F.; Ross, C.F. Chemical and sensory evaluation of astringency in Washington state red wines. Am. J. Enol. Viticult. 2008, 59, 153-158.

13. Charlton, A.; Baxter, N.; Khan, M.; Moir, A.; Haslam, E.; Davies, A.; Williamson, M. Polyphenol/peptide binding and precipitation. J. Agric. Food Chem. 2002, 50, 1593-1601.

14. Dinnella, C.; Recchia, A.; Fia, G.; Bertuccioli, M.; Monteleone, E. Saliva characteristics and individual sensitivity to phenolic astringent stimuli. Chem. Senses 2009, 34, 295-304.

15. Haslam, E. Natural polyphenols (vegetable tannins) as drugs: Possible modes of action. J. Nat. Prod. 1996, 59, 205-215.

16. Baxter, N.J.; Lilley, T.H.; Haslam, E.; Williamson, M.P. Multiple interactions between polyphenols and a salivary proline-rich protein repeat result in complexation and precipitation. Biochemistry 1997, 36, 5566-5577.

17. Hufnagel, J.C.; Hofmann, T. Orosensory-directed identification of astringent mouthfeel and bittertasting compounds in red wine. J. Agric. Food Chem. 2008, 56, 1376-1386.

18. Gawel, R. Red wine astringency: A review. Aust. J. Grape Wine Res. 1998, 4, 74-95. 
19. Kennedy, J.A.; Ferrier, J.; Harbertson, J.F.; Gachons, C.P.D. Analysis of tannins in red wine using multiple methods: Correlation with perceived astringency. Am. J. Enol. Viticult. 2006, 57, 481-485.

20. Vidal, S.; Francis, L.; Williams, P.; Kwiatkowski, M.; Gawel, R.; Cheynier, W.; Waters, E. The mouth-feel properties of polysaccharides and anthocyanins in a wine like medium. Food Chem. 2004, 85, 519-525.

21. Carvalho, E.; Mateus, N.; Plet, B.; Pianet, I.; Dufourc, E.; de Freitas, V. Influence of wine pectic polysaccharides on the interactions between condensed tannins and salivary proteins. J. Agric. Food Chem. 2006, 54, 8936-8944.

22. Gawel, R.; Francis, L.; Waters, E.J. Statistical correlations between the in-mouth textural characteristics and the chemical composition of Shiraz wines. J. Agric. Food Chem. 2007, 55, 2683-2687.

23. Vidal, S.; Francis, L.; Noble, A.; Kwiatkowski, M.; Cheynier, V.; Waters, E. Taste and mouthfeel properties of different types of tannin-like polyphenolic compounds and anthocyanins in wine. Anal. Chim. Acta 2004, 513, 57-65.

24. Fontoin, H.; Saucier, C.; Teissedre, P.-L.; Glories, Y. Effect of pH, ethanol and acidity on astringency and bitterness of grape seed tannin oligomers in model wine solution. Food Qual. Prefer. 2008, 19, 286-291.

25. Kallithraka, S.; Bakker, J.; Clifford, M.N. Red wine and model wine astringency as affected by malic and lactic acid. J. Food Sci. 1997, 62, 416-420.

26. Rossetti, D.; Bongaerts, J.H.H.; Wantling, E.; Stokes, J.R.; Williamson, A.M. Astringency of tea catechins: More than an oral lubrication tactile percept. Food Hydrocolloid. 2009, 23, 1984-1992.

27. de Wijk, R.A.; Prinz, J.F. The role of friction in perceived oral texture. Food Qual. Prefer. 2005, 16, 121-129.

28. Payne, C.; Bowyer, P.K.; Herderich, M.; Bastian, S.E.P. Interaction of astringent grape seed procyanidins with oral epithelial cells. Food Chem. 2009, 115, 551-557.

29. Brossaud, F.; Cheynier, V.; Noble, A.C. Bitterness and astringency of grape and wine polyphenols. Aust. J. Grape Wine Res. 2001, 7, 33-39.

30. Smith, A.K.; June, H.; Noble, A.C. Effects of viscosity on the bitterness and astringency of grape seed tannin. Food Qual. Prefer. 1996, 7, 161-166.

31. Bajec, M.R.; Pickering, G. Astringency: Mechanisms and perception. Crit. Rev. Food Sci. Nutr. 2008, $48,858-875$.

32. Luck, G.; Liao, H.; Murray, N.J.; Grimmer, H.R.; Warminski, E.E.; Williamson, M.P.; Lilley, T.H.; Haslam, E. Polyphenols, astringency and proline-rich proteins. Phytochemistry 1994, 37, 357-371.

33. Zanchi, D.; Poulain, C.; Konarev, P.; Tribet, C.; Svergun, D.I. Colloidal stability of tannins: astringency, wine tasting and beyond. J. Phys. Condens. Matter 2008, 20, 494224.

34. Obreque-Slier, E.; López-Solís, R.; Peña-Neira, A.; Zamora-Marín, F. Tannin-protein interaction is more closely associated with astringency than tannin-protein precipitation: experience with two oenological tannins and a gelatin. Int. J. Food Sci. Technol. 2010, 45, 2629-2636. 
35. Cheynier, V.; Duenas-Paton, M.; Salas, E.; Maury, C.; Souquet, J.M.; Sarni-Manchado, P.; Fulcrand, H. Structure and properties of wine pigments and tannins. Am. J. Enol. Viticult. 2006, 57, 298-305.

36. Stark, T.; Bareuther, S.; Hofmann, T. Sensory-guided decomposition of roasted cocoa nibs (Theobroma cacao) and structure determination of taste-active polyphenols. J. Agric. Food Chem. 2005, 53, 5407-5418.

37. Condelli, N.; Dinnella, C.; Cerone, A.; Monteleone, E.; Bertuccioli, M. Prediction of perceived astringency induced by phenolic compounds II: Criteria for panel selection and preliminary application on wine samples. Food Qual. Prefer. 2006, 17, 96-107.

38. de Freitas, V.; Mateus, N. Structural features of procyanidin interactions with salivary proteins. $J$ Agric. Food Chem. 2001, 49, 940-945.

39. Bennick, A. Interaction of plant polyphenols with salivary proteins. Crit. Rev. Oral Biol. Med. 2002, 13, 184-196.

40. Jöbstl, E.; O’Connell, J.; Fairclough, J.P.A.; Williamson, M.P. Molecular model for astringency produced by polyphenol/protein interactions. Biomacromolecules 2004, 5, 942-949.

41. Dangles, O.; Dufour, C. Flavonoid-protein interactions. In Flavonoids - Chemistry, Biochemistry and Applications; Andersen, O.M., Markham, K.R., Eds.; Taylor \& Francis: Boca Raton, FL, USA, 2006; pp. 443-470.

42. Croft, A.K.; Foley, M.K. Proline-rich proteins - deriving a basis for residue-based selectivity in polyphenolic binding. Org. Biomol. Chem. 2008, 6, 1594-1600.

43. Charlton, A.J.; Baxter, N.J.; Lilley, T.H.; Haslam, E.; McDonald, C.J.; Williamson, M.P. Tannin interactions with a full-length human salivary proline-rich protein display a stronger affinity than with single proline-rich repeats. FEBS Lett. 1996, 382, 289-292.

44. Pascal, C.; Paté, F.; Cheynier, V.; Delsuc, M. Study of the interactions between a proline-rich protein and a flavan-3-ol by NMR: Residual structures in the natively unfolded protein provides anchorage points for the ligands. Biopolymers 2009, 91, 745-756.

45. Canon, F.; Paté, F.; Meudec, E.; Marlin, T.; Cheynier, V.; Giuliani, A.; Sarni-Manchado, P. Characterization, stoichiometry, and stability of salivary protein-tannin complexes by ESI-MS and ESI-MS/MS. Anal. Bioanal. Chem. 2009, 395, 2535-2545

46. Lu, Y.; Bennick, A. Interaction of tannin with human salivary proline-rich proteins. Arch. Oral Biol. 1998, 43, 717-728.

47. Boze, H.; Marlin, T.; Durand, D.; Pérez, J.; Vernhet, A.; Canon, F.; Sarni-Manchado, P.; Cheynier, V.; Cabane, B. Proline-rich salivary proteins have extended conformations. Biophys. J. 2010, 99, 656-665.

48. Bacon, J.R.; Rhodes, M.J.C. Binding affinity of hydrolyzable tannins to parotid saliva and to proline-rich proteins derived from it. J. Agric. Food Chem. 2000, 48, 838-843.

49. Pascal, C.; Poncet-Legrand, C.; Cabane, B.; Vernhet, A. Aggregation of a proline-rich protein induced by epigallocatechin gallate and condensed tannins: Effect of protein glycosylation. $J$. Agric. Food Chem. 2008, 56, 6724-6732.

50. Sarni-Manchado, P.; Canals-Bosch, J.-M.; Mazerolles, G.; Cheynier, V. Influence of the glycosylation of human salivary proline-rich proteins on their interactions with condensed tannins. J. Agric. Food Chem. 2008, 56, 9563-9569. 
51. Yan, Q.; Bennick, A. Identification of histatins as tannin-binding proteins in human saliva. Biochem. J. 1995, 311, 341-347.

52. Naurato, N.; Wong, P.; Lu, Y.; Wroblewski, K.; Bennick, A. Interaction of tannin with human salivary histatins. J. Agric. Food Chem. 1999, 47, 2229-2234.

53. Sarneckis, C.; Dambergs, R.G.; Jones, P.; Mercurio, M.; Herderich, M.J.; Smith, P. Quantification of condensed tannins by precipitation with methyl cellulose: development and validation of an optimised tool for grape and wine analysis. Aust. J. Grape Wine Res. 2006, 12, 39-49.

54. Pocock, K.F.; Sefton, M.A.; Williams, P.J. Taste thresholds of phenolic extracts of French and American oakwood: The influence of oak phenols on wine flavor. Am. J. Enol. Viticult. 1994, 45, 429-434.

55. Peyrot des Gachons, C.; Kennedy, J.A. Direct method for determining seed and skin proanthocyanidin extraction into red wine. J. Agric. Food Chem. 2003, 51, 5877-5881.

56. Herderich, M.J.; Smith, P.A. Analysis of grape and wine tannins: Methods, applications and challenges. Aust. J. Grape Wine Res. 2005, 11, 1-10.

57. Busse-Valverde, N.; Gómez-Plaza, E.; López-Roca, J.M.; Gil-Muñoz, R.; Fernández- Fernández, J.I.; Bautista-Ortiń, A.B. Effect of different enological practices on skin and seed proanthocyanidins in three varietal wines. J. Agric. Food Chem. 2010, 58, 11333-11339.

58. Vidal, S.; Courcoux, P.; Francis, L.; Kwiatkowski, M.; Gawel, R.; Williams, P.; Waters, E.; Cheynier, V. Use of an experimental design approach for evaluation of key wine components on mouth-feel perception. Food Qual. Prefer. 2004, 15, 209-217.

59. Cheynier, V.; Prieur, C.; Guyot, S.; Rigaud, J.; Moutounet, M. The structures of tannins in grapes and wines and their interactions with proteins. In Wine - Nutritional and Therapeutic Benefits; Watkins, T.R., Ed.; ACS: Washington, DC, USA, 1997; pp. 81-93.

60. Kennedy, J.A.; Hayasaka, Y.; Vidal, S.; Waters, E.J.; Jones, G.P. Composition of grape skin proanthocyanidins at different stages of berry development. J. Agric. Food Chem. 2001, 49, 5348-5355.

61. Cosme, F.; Ricardo-Da-Silva, J.M.; Laureano, O. Tannin profiles of Vitis vinifera L. cv. red grapes growing in Lisbon and from their monovarietal wines. Food Chem. 2009, 112, 197-204.

62. Souquet, J.-M.; Cheynier, V.; Brossaud, F.; Moutounet, M. Polymeric proanthocyanidins from grape skins. Phytochemistry 1996, 43, 509-512.

63. Bindon, K.; Smith, P.; Kennedy, J.A. Interaction between grape-derived proanthocyanidins and cell wall material. 1. Effect on proanthocyanidin composition and molecular mass. J. Agric. Food Chem. 2010, 58, 2520-2528.

64. Monagas, M.; Bartolome, B.; Gomez-Cordoves, C. Updated knowledge about the presence of phenolic compounds in wine. Crit. Rev. Food Sci. Nutr. 2005, 45, 85-118.

65. Cheynier, V. Flavonoids in wine. In Flavonoids - Chemistry, Biochemistry and Applications; Andersen, O.M., Markham, K.R., Eds.; Taylor \& Francis: Boca Raton, FL, USA, 2006.

66. Riou, V.; Vernhet, A.; Doco, T.; Moutounet, M. Aggregation of grape seed tannins in model wine--effect of wine polysaccharides. Food Hydrocolloid. 2002, 16, 17-23.

67. Prieur, C.; Rigaud, J.; Cheynier, V.; Moutounet, M. Oligomeric and polymeric procyanidins from grape seeds. Phytochemistry 1994, 36, 781-784. 
68. Bindon, K.A.; Smith, P.A.; Holt, H.; Kennedy, J.A. Interaction between grape-derived proanthocyanidins and cell wall material. 2. Implications for vinification. J. Agric. Food Chem. 2010, 58, 10736-10746.

69. Lee, J.; Kennedy, J.A.; Devlin, C.; Redhead, M.; Rennaker, C. Effect of early seed removal during fermentation on proanthocyanidin extraction in red wine: A commercial production example. Food Chem. 2008, 107, 1270-1273.

70. Souquet, J.-M.; Labarbe, B.; Guernevé, C.L.; Cheynier, V.; Moutounet, M. Phenolic composition of grape stems. J. Agric. Food Chem. 2000, 48, 1076-1080.

71. Vivas, N.; Nonier, M.F.; Gaulejac, N.V.d. Structural characterization and analytical differentiation of grape seeds, skins, stems and Quebracho tannins. Bull. OIV 2004, 77, 643-659.

72. Cala, O.; Pinaud, N.; Simon, C.; Fouquet, E.; Laguerre, M.; dufourc, E.J.; Pianet, I. NMR and molecular modeling of wine tannins binding to saliva proteins: revisiting astringency from molecular and colloidal prospects. FASEB J. 2010, 24, 1-10.

73. Fulcrand, H.; Duenas, M.; Salas, E.; Cheynier, V. Phenolic reactions during winemaking and aging. Am. J. Enol. Viticult. 2006, 57, 289-297.

74. Drinkine, J.; Glories, Y.; Saucier, C. (+)-Catechin-aldehyde condensations: Competition between acetaldehyde and glyoxylic acid. J. Agric. Food Chem. 2005, 53, 7552-7558.

75. Es-Safi, N.E.; Fulcrand, H.; Cheynier, V.; Moutounet, M. Studies on the acetaldehyde-induced condensation of (-)-epicatechin and malvidin 3-O-glucoside in a model solution system. J. Agric. Food Chem. 1999, 47, 2096-2102.

76. Dallas, C.; Ricardo-da-Silva, J.M.; Laureano, O. Interactions of oligomeric procyanidins in model wine solutions containing malvidin-3- - glucoside and acetaldehyde. J. Sci. Food Agric. 1996, 70, 493-500.

77. Dallas, C.; Ricardo-da-Silva, J.M.; Laureano, O. Products formed in model wine solutions involving anthocyanins, procyanidin B2, and acetaldehyde. J. Agric. Food Chem. 1996, 44, 2402-2407.

78. Poncet-Legrand, C.; Cabane, B.; Bautista-Ortín, A.; Carrillo, S.; Fulcrand, H.; Pérez, J.; Vernhet, A. Tannin oxidation: Intra- versus intermolecular reactions. Biomacromolecules 2010, 11, 2376-2386.

79. McRae, J.M.; Falconer, R.J.; Kennedy, J.A. Thermodynamics of grape and wine tannin interaction with polyproline: Implications for red wine astringency. J. Agric. Food Chem. 2010, 58, 12510-12518.

80. Haslam, E. In Vino Veritas - Oligomeric procyanidins and the aging of red wines. Phytochemistry 1980, 19, 2577-2582.

81. Mateus, N.; Oliveira, J.; Pissarra, J.; Gonzalez-Paramas, A.M.; Rivas-Gonzalo, J.C.; SantosBuelga, C.; Silva, A.M.S.; de Freitas, V. A new vinylpyranoanthocyanin pigment occurring in aged red wine. Food Chem. 2006, 97, 689-695.

82. Mateus, N.; Silva, A.M.S.; Rivas-Gonzalo, J.C.; Santos-Buelga, C.; De Freitas, V. A new class of blue anthocyanin-derived pigments isolated from red wines. J. Agric. Food Chem. 2003, 51, 1919-1923. 
83. Salas, E.; Atanasova, V.; Poncet-Legrand, C.; Meudec, E.; Mazauric, J.P.; Cheynier, V. Demonstration of the occurrence of flavanol-anthocyanin adducts in wine and in model solutions. Anal. Chim. Acta 2004, 513, 325-332.

84. Salas, E.; Fulcrand, H.; Poncet-LeGrand, C.; Meudec, E.; Kohler, N.; Winterhalter, P.; Cheynier, V. Isolation of flavanol-anthocyanin adducts by countercurrent chromatography. J. Chromatogr. Sci. 2005, 43, 488-493.

85. Fulcrand, H.; Atanasova, V.; Salas, E.; Cheynier, V. The fate of anthocyanins in wine: Are there determining factors? In Red Wine Color - Revealing the Mysteries; Waterhouse, A.L., Kennedy, J.A., Eds.; American Chemical Society: Washington, DC, USA, 2004; pp. 68-88.

86. Mateus, N.; de Freitas, V. Evolution and stability of anthocyanin-derived pigments during port wine aging. J. Agric. Food Chem. 2001, 49, 5217-5222.

87. Simon, C.; Barathieu, K.; Laguerre, M.; Schmitter, J.-M.; Fouquet, E.; Pianet, I.; Dufourc, E.J. Three-dimensional structure and dynamics of wine tannin-saliva protein complexes, a multitechnique approach. Biochemistry 2003, 42, 10385-10395.

88. Wróblewski, K.; Muhandiram, R.; Chakrabartty, A.; Bennick, A. The molecular interaction of human salivary histatins with polyphenolic compounds. Eur. J. Biochem. 2001, 268, 4384-4397.

89. Hagerman, A.E.; Rice, M.E.; Ritchard, N.T. Mechanisms of protein precipitation for two tannins, pentagalloyl glucose and epicatechin16 (4f8) catechin (procyanidin). J. Agric. Food Chem. 1998, 46, 2590-2595.

90. Kawamoto, H.; Nakatsubo, F. Effects of environmental factors on two-stage tannin-protein coprecipitation. Phytochemistry 1997, 46, 479-483.

91. Vidal, S.; Francis, L.; Guyot, S.; Marnet, N.; Kwiatkowski, M.; Gawel, R.; Cheynier, V.; Waters, E.J. The mouth-feel properties of grape and apple proanthocyanidins in a wine-like medium. $J$. Sci. Food Agr. 2003, 83, 564-573.

92. Hofmann, T.; Glabasnia, A.; Schwarz, B.; Wisman, K.N.; Gangwer, K.A.; Hagerman, A.E. Protein binding and astringent taste of a polymeric procyanidin, 1,2,3,4,6-penta-O-galloyl-beta-Dglucopyranose, castalagin, and grandinin. J. Agric. Food Chem. 2006, 54, 9503-9509.

93. Cheynier, V.; Duenas-Paton, M.; Salas, E.; Maury, C.; Souquet, J.M.; Sarni-Manchado, P.; Fulcrand, H. Structure and properties of wine pigments and tannins. Am. J. Enol. Viticult. 2006, 57, 298-305.

94. Poncet-Legrand, C.; Edelmann, A.; Putaux, J.-L.; Cartalade, D.; Sarni-Manchado, P.; Vernhet, A. Poly(L-proline) interactions with flavan-3-ols units: Influence of the molecular structure and the polyphenol/protein ratio. Food Hydrocolloid. 2003, 20, 687-697.

95. Deaville, E.R.; Green, R.J.; Mueller-Harvey, I.; Willoughby, I.; Frazier, R.A. Hydrolyzable tannin structures influence relative globular and random coil protein Binding Strengths. J. Agric. Food Chem. 2007, 55, 4554-4561.

96. Richard, T.; Lefeuvre, D.; Descendit, A.; Quideau, S.; Monti, J.P. Recognition characters in peptide-polyphenol complex formation. BBA Gen. Subjects 2006, 1760, 951-958.

97. Poncet-Legrand, C.; Gautier, C.; Cheynier, V.; Imberty, A. Interactions between flavan-3-ols and poly(L-proline) studied by Isothermal Titration Calorimetry: Effect of the tannin structure. $J$. Agric. Food Chem. 2007, 55, 9235-9240. 
98. Le Bourvellec, C.; Guyot, S.; Renard, C.M.G.C. Non-covalent interaction between procyanidins and apple cell wall material: Part I. Effect of some environmental parameters. BBA Gen. Subjects 2004, 1672, 192-202.

99. Tarascou, I.; Barathieu, K.; Simon, C.; Ducasse, M.A.; Andre, Y.; Fouquet, E.; Dufourc, E.J.; de Freitas, V.; Laguerre, M.; Pianet, I. A 3D structural and conformational study of procyanidin dimers in water and hydro-alcoholic media as viewed by NMR and molecular modeling. Magn. Reson. Chem. 2006, 44, 868-880.

100. Cala, O.; Fabre, S.; Fouquet, E.; Dufourc, E.J.; Pianet, I. NMR of human saliva protein/wine tannin complexes. Towards deciphering astringency with physico-chemical tools. C.R. Chim. 2010, 13, 449-452.

101. Vivar-Quintana, A.M.; Santos-Buelga, C.; Rivas-Gonzalo, J.C. Anthocyanin-derived pigments and colour of red wines. Anal. Chim. Acta 2002, 458, 147-155.

102. Morata, A.; Gómez-Cordovés, M.C.; Calderón, F.; Suárez, J.A. Effects of pH, temperature and $\mathrm{SO}_{2}$ on the formation of pyranoanthocyanins during red wine fermentation with two species of Saccharomyces. Int. J. Food Microbiol. 2006, 106, 123-129.

103. Li, H.; Guo, A.; Wang, H. Mechanisms of oxidative browning of wine. Food Chem. 2008, 108, $1-13$.

104. Waters, E.J.; Peng, Z.; Pocock, K.F.; Jones, G.P.; Clarke, P.; Williams, P.J. Solid-state ${ }^{13}$ C NMR investigation into insoluble deposits adhering to the inner glass surface of bottled red wine. $J$. Agric. Food Chem. 1994, 1994, 1761-1766.

105. Herderich, M.; Birse, M.; Dambergs, R.; Holt, H.; Iland, P.; Lattey, K.; Smith, P.A. Grape and wine tannins - an overview on current research, emerging applications, and future challenges. In Advances in Tannin and Tannin Management, Proceedings of AWRI Roadshow seminar, Adelaide Convention Centre, Australia, 6 October 2005; Allen, M., Dundon, C., Francis, M., Howell, G.S., Wall, G., Eds.; Australian Society of VIticulture and Oenology: Adelaide, Australia, 2006; pp. 4-10.

106. Parish, M.; Wollan, D.; Paul, R. Micro-oxygenation - A Review. Aust. N. Z. Grapegrower Winemaker 2000, 438a, 47-50.

107. Pozo, A.G.-d.; Arozarena, I.; Noriega, M.-J.; Navarro, M.; Casp, A. Short- and long-term effects of micro-oxygenation treatments on the colour and phenolic composition of a Cabernet Sauvignon wine aged in barrels and/or bottles. Eur. Food Res. Technol. 2010, 231, 589-601.

108. González-Sanjosé, M.L.; Ortega-Heras, M.; Pérez-Magariño, S. Microoxygenation treatment and sensory properties of young red wines. Food Sci. Technol. Int. 2008, 14, 123-130.

109. Cano-Lopez, M.; Pardo-Minguez, F.; López-Roca, J.; Gómez-Plaza, E. Chromatic characteristics and anthocyanin profile of a micro-oxygenated red wine after oak or bottle maturation. Eur. Food Res. Technol. 2007, 225, 127-132.

110. Llaudy, M.D.; Canals, R.; Gonzalez-Manzano, S.; Canals, J.M.; Santos-Buelga, C.; Zamora, F. Influence of micro-oxygenation treatment before oak aging on phenolic compounds composition, astringency, and color of red wine. J. Agric. Food Chem. 2006, 54, 4246-4252.

111. Ross, C.F.; Weller, K. Effect of serving temperature on the sensory attributes of red and white wines. J. Sens. Stud. 2008, 23, 398-416. 
112. Obreque-Slíer, E.; Peña-Neira, A.; López-Solís, R. Enhancement of both salivary proteinenological tannin interactions and astringency perception by ethanol. J. Agric. Food Chem. 2010, 58, 3729-3735.

113. Poncet-Legrand, C.; Cartalade, D.; Putaux, J.-L.; Cheynier, V.; Vernhet, A. Flavan-3-ol aggregation in model ethanolic solutions:Incidence of polyphenol structure, concentration, ethanol content, and ionic strength. Langmuir 2003, 19, 10563-10572.

114. Zanchi, D.; Konarev, P.V.; Tribet, C.; Baron, A.; Svergun, D.I.; Guyot, S. Rigidity, conformation, and solvation of native and oxidized tannin macromolecules in water-ethanol solution. J. Chem. Phys. 2009, 130, 245103.

115. Zanchi, D.; Vernhet, A.; Poncet-Legrand, C.; Cartalade, D.; Tribet, C.; Schweins, R.; Cabane, B. Colloidal dispersions of tannins in water-ethanol solutions. Langmuir 2007, 23, 9949-9959.

116. Kallithraka, S.; Bakker, J.; Clifford, M.N. Effect of pH on astringency in model solutions and wines. J. Agric. Food Chem. 1997, 45, 2211-2216.

117. Borse, B.B.; Rao, L.J.M.; Ramalakshmi, K.; Raghavan, B. Chemical composition of volatiles from coconut sap (neera) and effect of processing. Food Chem. 2006, 101, 877-880.

118. Escot, S.; Feuillat, M.; Dulau, L.; Charpentier, C. Release of polysaccharides by yeasts and the influence of released polysaccharides on colour stability and wine astringency. Aust. J. Grape Wine Res. 2001, 7, 153-159.

119. Taira, S.; Ono, M.; Matsumoto, N. Reduction of persimmon astringency by complex formation between pectin and tannins. Postharvest Biol. Technol. 1997, 12, 265-271.

120. McManus, J.P.; Davis, K.G.; Beart, J.E.; Gaffney, S.H.; Lilley, T.H.; Haslam, E. Polyphenol interactions. part 1. introduction; some observations on the reversible complexation of polyphenols with proteins and polysaccharides. J. Chem. Soc.-Perk. T 2 1985, 1429-1438.

121. Soares, S.I.; Gonçalves, R.M.; Fernandes, I.; Mateus, N.; de Freitas, V. Mechanistic approach by which polysaccharides inhibit $\alpha$-amylase/procyanidin aggregation. J. Agric. Food Chem. 2009, $57,4352-4358$.

122. Poncet-Legrand, C.; Doco, T.; Williams, P.; Vernhet, A. Inhibition of grape seed tannin aggregation by wine mannoproteins: Effect of polysaccharide molecular weight. Am. J. Enol. Viticult. 2007, 58, 87-91.

123. Boselli, E.; Minardi, M.; Giomo, A.; Frega, N.G. Phenolic composition and quality of white d.o.c. wines from Marche (Italy). Anal. Chim. Acta 2006, 563, 93-100.

124. Ishikawa, I.; Noble, A.C. Temporal perception of astringency and sweetness in red wine. Food Qual. Prefer. 1995, 6, 27-33.

125. Sáenz-Navajas, M.P.; Tao, Y.S.; Dizy, M.; Ferreira, V.; Fernández-Zurbano, P. Relationship between nonvolatile composition and sensory properties of premium Spanish red wines and their correlation to quality perception. J. Agric. Food Chem. 2010, 58, 12407-12416.

Sample Availability: Not available.

(C) 2011 by the authors; licensee MDPI, Basel, Switzerland. This article is an open access article distributed under the terms and conditions of the Creative Commons Attribution license (http://creativecommons.org/licenses/by/3.0/). 